\title{
Distribution of Human Papillomavirus Genotypes in Sardinian Patients with Oral Squamous Cell Carcinoma
}

\author{
Caterina Montaldo*, Andrea Mastinu, Stefania Zorco, Noemi Santini, Elisabetta Pisano, Vincenzo Piras, \\ Gloria Denotti, Carla Peluffo, Matteo Erriu, Valentino Garau and Germano Orrù
}

\author{
Surgery Department of Odontostomatological Sciences, Odontostomatology Section, O.B.L., University of Cagliari, \\ Cagliari, Italy
}

\begin{abstract}
Human papillomaviruses (HPVs) seem to play an important role in the pathogenesis of gynecological carcinomas and in head and neck carcinomas. The aim of this study was to detect and genotype HPVs in fresh oral squamous cell carcinoma (OSCC) from a Sardinian population, and to determine whether HPV presence was significantly associated with the development of OSCC.

The oral mucosa tissues were obtained from 120 samples (68 OSCC and 52 control samples) taken from a Sardinian population seen at the Dental Clinic of the Department of Surgery and Odontostomatological Sciences, University of Cagliari (Italy) and the "Ospedale SS Trinità", Cagliari (A.S.L. 8) between 2007 and 2008. PCR was used for the detection of HPV DNA and the genotype was determined by DNA sequencing. The frequency of HPV infection was evaluated in relation to age, sex, smoking and alcohol use. Statistical analysis was performed using the SPSS 11.5 software.

The results showed the presence of HPV-DNA in $60.3 \%$ of OSCC with HPV-16 $(51.2 \%)$ being the most frequent genotype. In these Sardinian OSCC patients, HPV-DNA was detected more in males $(65.8 \%)$ than in females (34.1\%) while controls show a $0 \%$ of HPV presence. HPV positive was highly associated with OSCC among subjects with a history of heavy tobacco and alcohol use and among those with no such history.

A greater frequency of high risk HPV presence was observed in patients with OSCC compared to health control patients. In addition these results suggested that oral HPV presence could be associated in OSCC subjects. Our results need more analyses to detect the HPV-DNA integration into tumoral cells.
\end{abstract}

Keywords: HPV, oral squamous cell carcinoma, seminested PCR, Sardinian patients.

\section{INTRODUCTION}

Squamous cell carcinoma (SCC) is the most common malignant tumor of the oral cavity and one of the ten most common causes of death. In addition the incidence of oral squamous cell carcinoma (OSCC) of the oral cavity and oropharynx is increasing worldwide [1]. The annual incidence and mortality rates vary considerably between different races, genders, and age groups; however, as reported in previous publications, the risk of intra-oral cancer rises with increasing age especially for males [1-4]. Many risk factors have been reported by different authors such as: tobacco use and alcohol consumption which are the main risk factors for this group of cancer [5]. However, these cancers also occur among lifelong tobacco and alcohol abstainers and, thus, other risk factors such as conditions related to oral health and hygiene (i.e. poor condition of the mouth, dentition, bleeding gums, and mouthwash use) have been suspected as contributing to its etiology.

*Address correspondence to this author at the Surgery Department of Odontostomatological Sciences, Odontostomatology Section, O.B.L., University of Cagliari, Via Binaghi ${ }^{\circ} 4$, 09121 Cagliari, Italy; Tel: 0039 070.537417; Fax: 0039 070.537437; E-mail: montaldc@unica.it
In this context, Human papillomavirus (HPV) as a prognostic risk for OSSC has not yet been extensively studied, a reason for this "defect" could be due to: (i) unusual or less sensitive technologies for HPV detection in SSC, (ii) in excess of 100 HPV genotypes are recognized based on specific DNA sequence variations and 30-40 are associated with sexual lesions. However, the oncogenic capacity of individual HPV types differs considerably [6-8]. This virus is epitheliotropic and in humans is associated with papillomatosis, hyperplastic, and verrucous lesions on the skin and mucous membranes of various sites [9]. These genotypes, which are frequently identified in cellular neoplasm, have been segregated into those with a low risk and those with a high risk of malignant transformation [10]. Indeed, some authors have shown that high-risk viral genotypes such as HPV 16, 18, 31 and 33, are frequently associated with leukoplakia and squamous carcinoma [11, 12]. On the contrary low-risk types, such as HPV 6, 11, 13, 32 are preferentially associated with benign proliferative epithelial lesions e.g. squamous papilloma, condyloma acuminatum, verruca vulgaris and focal epithelial hyperplasia [13]. Functionally high-risk HPV infection contributes to carcinogenesis and tumor progression through two viral oncogenes E6 and E7 [9]. These oncogenes inhibit the activities of the p53 and pRb, and, have been considered 
as an important feature in disrupting cell-cycle regulatory pathways leading to a genetic progression to oral squamous cell carcinoma (OSCC) [14].

The frequency of HPV in oral lesions varies with geographic occurrence [15], the type of lesion [16] and the diagnostic methodology [17]. The diagnosis of HPV infection is based on the use of advanced molecular tools [18]. Polymerase chain reaction (PCR) and sequencing are considered the most sensitive and rapid methods for the detection and genotyping of HPV-DNA, respectively [1921].

The present study was conducted to investigate the distribution of HPV in Sardinian patients with malignant oral mucosal lesions compared with healthy patients. An association between HPV-16, HPV -31 exposure and OSCC was also evaluated among subjects with different use of tobacco and alcohol.

\section{MATERIALS AND METHODOLOGY}

\section{Clinical Samples}

The oral mucosa fresh tissues were obtained from 120 samples (mean age 61.4, age range: 22-86, 69 men and 51 women). Sixty-eight were from the patients with OSCC seen at the "Ospedale SS Trinità", Cagliari (A.S.L. 8) between 2007 and 2008. Fifty-two control samples were from volunteers randomly chosen from patients at the Department of Dental Disease Prevention (University of Cagliari). These controls reported no history of cancer or showed no sign of mucosal lesions or relevant systemic disease. At the time of examination, all participants were informed about the research and its purpose and gave their informed consent.

An incisional biopsy of the oral squamous cell carcinoma (OSCC) lesion was performed on each patient. All biopsies were divided into two parts: one part was used for histopathological analysis and the other was frozen at $-80^{\circ} \mathrm{C}$ until a molecular assay could be performed. Each fresh specimen sample was analyzed and histopathologically classified as regards to OSCC. Information on patient gender, age, smoking and alcohol history was collected from direct patient interviews and medical records. Tumor grade and staging system (TNM) were obtained from clinical notes, histopathology and radiology reports. Staging was carried out according to the Fifth Edition of the International Cancer Union guidelines [22].

\section{Extraction, Amplification and Sequencing}

About $25 \mathrm{mg}$ of tissue was finely crushed and the DNA was extracted with a QIAamp ${ }^{\circledR}$ DNA Mini Kit (Qiagen) according to the manufacturer's instructions, quantified by spectrophotometry and frozen at $-80^{\circ} \mathrm{C}$ until use. The molecular method for the detection of HPV-DNA was Seminested PCR. In the first reaction the degenerate primers MY09 (5'-CGT CC(AC) AA(AG) GGA (AT)AC TGA TC3') and MY11 (5'-GC(AC) CAG GG(AT) CAT AA(CT) AAT GG-3') were used to amplify a $450 \mathrm{bp}$ fragment in the L1 gene [23]. The first reaction was performed in a final volume of $25 \mathrm{ul}$, consisting of $4 \mathrm{ul}$ extracted DNA as a template $(100 \mathrm{ng}), 2.5 \mathrm{ul}$ of a 10X PCR buffer $(200 \mathrm{mM}$ Tris- $\mathrm{HCl}, 500 \mathrm{mM} \mathrm{KCl}, \mathrm{pH}$ 8.4), $1.5 \mathrm{mM}$ magnesium chloride, a deoxyribonucleotide triphosphate mixture $(0.2$
$\mathrm{mM}$ of each), $0.5 \mathrm{uM}$ of each primers, $2.5 \mathrm{ul} \mathrm{U}$ Platinum Taq DNA Polymerase and 4 ul of the Rnasi Dnasi-free template. All reagents were purchased from Invitrogen (Milan, Italy) with the exception of the primers. The mixture was incubated for 2 minutes at $95^{\circ} \mathrm{C}$ and subjected to 20 cycles of amplification $\left(95^{\circ} \mathrm{C}\right.$ for 30 seconds, $52^{\circ} \mathrm{C}$ (MY09/MY11) for 1 minute; and $72^{\circ} \mathrm{C}$ for 30 seconds) with a final extension at $72^{\circ} \mathrm{C}$ for 5 minutes in a thermal cycler (Eppendorf, Milan, Italy). Two micro-liters of the PCR product of the first reaction were taken for the PCR second round, with the primer MY09 in conjunction with a new second primer, GP5+N (5'-TTTGTTACTGTGGTAGATAC-3') to reamplify the material generated in the first round, thus generating a 407 base pair fragment. The second reaction was performed in a final volume of $25 \mathrm{ul}$ and contained 2.5 ul of a 10X PCR buffer (200 mM Tris- $\mathrm{HCl}, 500 \mathrm{mM} \mathrm{KCl}$, $\mathrm{pH}$ 8.4), $1.0 \mathrm{mM}$ magnesium chloride, a deoxyribonucleotide triphosphate mixture $(0.2 \mathrm{mM}$ of each), $0.5 \mathrm{uM}$ of each primers and $2.5 \mathrm{ul} \mathrm{U}$ Platinum Taq DNA Polymerase. Initial denaturation for 2 minutes at $95^{\circ} \mathrm{C}$ was followed by 40 cycles. Each of the cycles consisted of denaturation for 30 seconds at $94^{\circ} \mathrm{C}$, annealing for 30 seconds at $47^{\circ} \mathrm{C}$ and chain elongation for 1 minute at $72^{\circ} \mathrm{C}$. One cycle of chain elongation was took for 7 minutes at $72^{\circ} \mathrm{C}$ at the end. The PCR products were electrophoresed on 2\% agarose gels, stained with sybr green $1.5 \%$ and visualized under an ultraviolet transilluminator. The beta-globin gene was detected (data not shown) in all specimens to confirm the presence of amplifiable DNA in the extracted specimens.

PCR products were purified with a QIAquick Purification PCR kit (Qiagen, Milan, Italy) and were sequenced by a conventional capillary ABI Prism 310 automatic sequencer (Applied Biosystems Foster City, Calif.). The results were edited and analyzed with a Basic Local Alignment Search Tool [24].

Statistical analysis was performed using the SPSS 11.5 software. Data are expressed as the number of percentages detected. All data were compared using the Chi-Square and Fisher exact with significance considered to be $\mathrm{P}<0.05$.

\section{RESULTS}

HPV-DNA was detected in 120 tissue samples: 68 oral squamous cell carcinoma and 52 control samples. The age of the patients with OSCC ranged from 27-86 (mean age: 65.6), with 47 males aged between 35-86 (mean age: 61.4 ) and 21 females aged between 27-84 (mean age: 64.9). The age range of the control patients was 22-85 (mean age: 56.8); 25 males were aged between 40-85 (mean age 57.5) and 27 females between 22-84 (mean age 56.3). Table 1 summarizes the information on HPV-positive patient gender, age. Using the Blast program, the HPV sequences obtained from positive samples showing a representative nucleotide motif were submitted to the DNA data Bank GenBank [24] with the following accession numbers: DQ286926, DQ312262, DQ312263.

Of the 68 OSCC samples $41(41 / 68,60.3 \%)$ were positive for HPV-DNA and indicated by a 407-bp fragment on $2 \%$ agarose gel electrophoresis of the PCR products (Fig. 1). Presence of faint bands was read as partial positives that need a confirmation by the sequencing. 
Table 1. OSCC Positive for HPV DNA

\begin{tabular}{|c|c|c|c|c|}
\hline $\begin{array}{l}\text { Positive } \\
\text { Samples }\end{array}$ & $\begin{array}{l}\text { Age } \\
\text { Years }\end{array}$ & Gender & $\begin{array}{l}\text { HPV } \\
\text { Type }\end{array}$ & $\begin{array}{c}\text { Oral } \\
\text { Lesions }\end{array}$ \\
\hline 1 & 50 & $\mathrm{M}$ & 31 & OSCC \\
\hline 2 & 53 & M & 31 & OSCC \\
\hline 3 & 58 & $\mathrm{M}$ & 31 & OSCC \\
\hline 4 & 50 & M & 31 & OSCC \\
\hline 5 & 63 & $\mathrm{M}$ & 31 & OSCC \\
\hline 6 & 58 & $\mathrm{M}$ & 31 & OSCC \\
\hline 7 & 50 & F & 6 & OSCC \\
\hline 8 & 66 & $\mathrm{~F}$ & 16 & OSCC \\
\hline 9 & 79 & $\mathrm{~F}$ & 16 & OSCC \\
\hline 10 & 56 & $\mathrm{M}$ & 16 & OSCC \\
\hline 11 & 72 & $\mathrm{~F}$ & 6 & OSCC \\
\hline 12 & 60 & $\mathrm{~F}$ & 16 & OSCC \\
\hline 13 & 51 & $\mathrm{~F}$ & 16 & OSCC \\
\hline 14 & 76 & $\mathrm{M}$ & 6 & OSCC \\
\hline 15 & 68 & $\mathrm{~F}$ & 16 & OSCC \\
\hline 16 & 60 & M & 55 & OSCC \\
\hline 17 & 80 & $\mathrm{~F}$ & 16 & OSCC \\
\hline 18 & 35 & M & 16 & OSCC \\
\hline 19 & 78 & $\mathrm{M}$ & 16 & OSCC \\
\hline 20 & 61 & $\mathrm{~F}$ & 16 & OSCC \\
\hline 21 & 54 & $\mathrm{~F}$ & 16 & OSCC \\
\hline 22 & 51 & $\mathrm{~F}$ & 16 & OSCC \\
\hline 23 & 39 & $\mathrm{M}$ & 16 & OSCC \\
\hline 24 & 52 & $\mathrm{~F}$ & 31 & OSCC \\
\hline 25 & 67 & $\mathrm{M}$ & 16 & OSCC \\
\hline 26 & 58 & M & 16 & OSCC \\
\hline 27 & 74 & $\mathrm{M}$ & 16 & OSCC \\
\hline 28 & 71 & $\mathrm{M}$ & 16 & OSCC \\
\hline 29 & 73 & $\mathrm{M}$ & 16 & OSCC \\
\hline 30 & 49 & $\mathrm{M}$ & 16 & OSCC \\
\hline 31 & 63 & $\mathrm{M}$ & 16 & OSCC \\
\hline 32 & 74 & $\mathrm{M}$ & 6 & OSCC \\
\hline 33 & 61 & $\mathrm{M}$ & 6 & OSCC \\
\hline 34 & 65 & $\mathrm{M}$ & 6 & OSCC \\
\hline 35 & 78 & $\mathrm{M}$ & 6 & OSCC \\
\hline 36 & 70 & $\mathrm{M}$ & 6 & OSCC \\
\hline 37 & 84 & $\mathrm{~F}$ & 6 & OSCC \\
\hline 38 & 59 & M & 16 & OSCC \\
\hline 39 & 78 & M & 6 & OSCC \\
\hline 40 & 72 & $\mathrm{~F}$ & 6 & OSCC \\
\hline 41 & 59 & M & 6 & OSCC \\
\hline
\end{tabular}

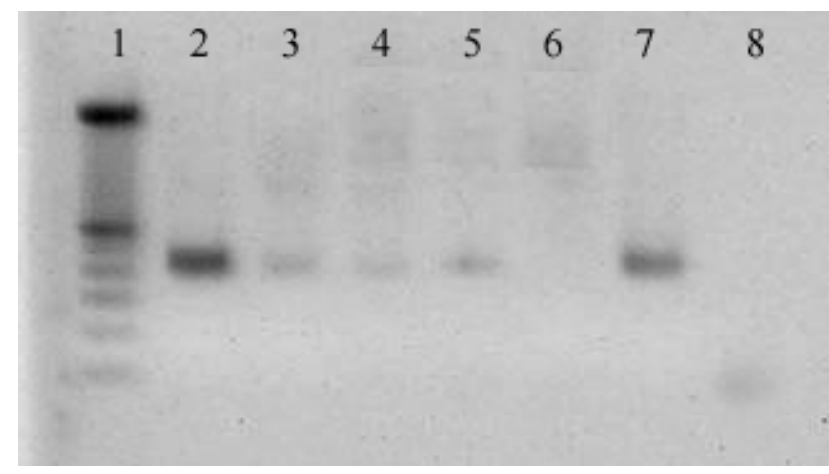

DNA from oral tissue was amplified by seminested polymerase chain reaction.

Fig. (1). This figure shows the amplicon of the second round reaction generating a $407 \mathrm{bp}$ fragment on $2 \%$ agarose gel electrophoresis. Lane 1 is Marker $100 \mathrm{bp}$, lanes 2, 3, 4 and 5 are positive samples confirmed by nucleotide DNA sequencing, lane 6 is a negative sample. Lane 7 is the positive HPV control and lane 8 is the negative control. Some sequences of HPV types 6 and 31 were submitted to the DNA data Bank (GenBank http://www.ncbi.nlm.nih.gov/BLAST/) with the following accession numbers: DQ286926, DQ312262, DQ312263. The betaglobin gene was detected (data not shown) in all specimens to confirm the presence of amplificable DNA in the extracted specimens.

Whereas twenty-eight carcinoma samples $(28 / 41,68.3 \%)$ were positive for a high-risk subtype (21/41, 51.2\% HPV-16 and $7 / 41,17 \%$ HPV-31) only 13 samples out of $41(34.14 \%)$ were positive for low-risk subtype (12/41, 29.3\% HPV-6 and 1/41, 2.4\% HPV-55) (Fig. 2). We were unable to find HPV presence in the 52 samples forming the control group. Moreover, post hoc analysis showed a significant effect for the differences between the OSCC patients and the control group $(\mathrm{P}<0.05)$ for the prevalence of HPV-DNA.

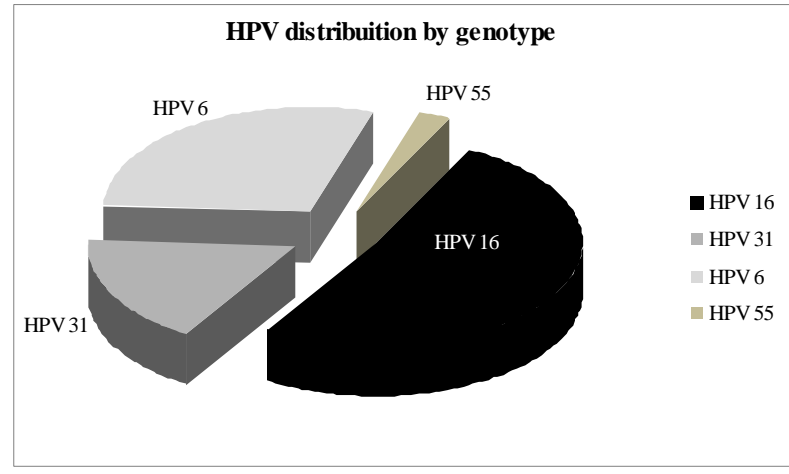

Fig. (2). Frequency in percentage of different HPV genotypes in OSCC samples. Samples positive on seminested PCR were subjected to nucleotide DNA sequencing. Alignments were obtained from the GenBank online BLAST server and HPV sequences were downloaded from the HPV database.

As regards virus distribution between genders (Fig. 3), we observed significant differences in HPV frequency between males and females with OSCC from a Sardinian population, $65.8 \%$ vs $34.1 \%$, respectively. Furthermore, in subjects over 50 years, a significant increase in HPV DNA $(\mathrm{P}<0.05)$ was detected with advancing age $(8 \%<49$ years and $92 \%>49$ years) (Fig. 4 ). 


\section{Males and Females with HPV}

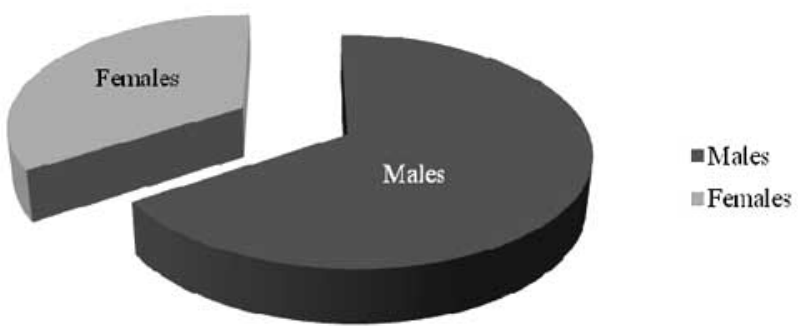

Fig. (3). Presence in the OSCC human papillomavirus (HPV) in relationship to sex, expressed as a frequency percentage. We observed significant differences in HPV frequency between males and females with OSCC from a Sardinian population, $65.8 \%$ vs $34.1 \%$, respectively. Was not observed the HPV DNA in our control group.

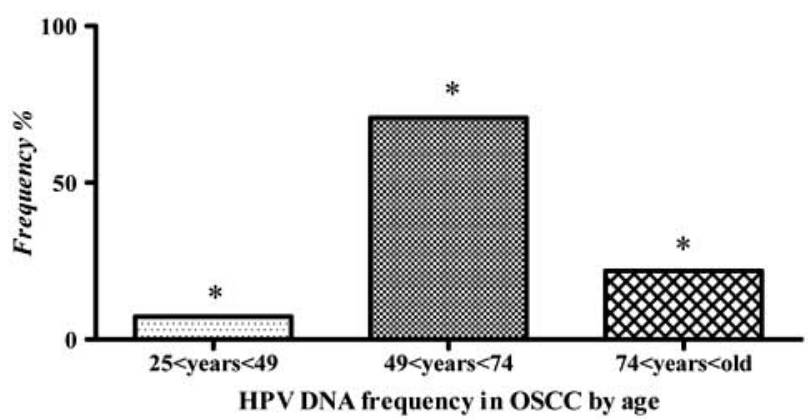

Fig. (4). Distribution of HPV in relationship to age, expressed as a frequency percentage. Over 50 years of age a significant increase HPV DNA of the OSCC samples was found.

Table 2 shows the lack of statistical associations between the presence of the virus and other known risk factors such as smoking and alcohol. We did not observe a significant difference between HPV high risk presence and tobacco and alcohol use in patients with OSCC.

Table 2. Samples Positive for HPV High Risk and Tobacco and Alcohol Use

\begin{tabular}{|c|c|c|c|}
\hline & $\begin{array}{c}\text { HPV +, } \\
\text { High Risk, } \\
\mathbf{n}=\mathbf{2 8}\end{array}$ & $\begin{array}{c}\text { HPV - } \\
\mathbf{n = 2 7}\end{array}$ & P Value \\
\hline \hline Tobacco and alcohol use & $35(64.3 \%)$ & $10(37.0 \%)$ & $\mathrm{P}=0.351$ \\
\hline $\begin{array}{c}\text { Abstain completely from } \\
\text { Alcohol and tobacco }\end{array}$ & $10(35.7 .6 \%)$ & $17(63 \%)$ & $\mathrm{P}=0.509$ \\
\hline
\end{tabular}

\section{DISCUSSION}

This study was set up to establish the prevalence and HPV genotypes in Sardinian patients with OSCC compared with a group of healthy patients. According to scientific literature, several types of HPV, particularly type 16, have been found to be associated with oropharyngeal squamouscell carcinoma, a form of head and neck cancer.

The role of HPV in the development of uterine cervix lesions has been demonstrated by many studies [25]; it still remains a controversial issue as regards oral lesions [26-28].
Contradictory results reported on HPV infection in oral mucosa are mainly due to differences in detection methods and the epidemiological characteristics of the observed populations [29, 30]. Several reports have indeed utilized different molecular techniques (in situ hybridization [31] and Southern Blot analysis [32, 33] from several sample typologies (mouthwashes, in scrapings and in paraffinembedded tissue) $[12,34]$.

Over the past 20 years, there has been an increasing interest in HPVs as regards their potential role in the pathogenesis of OSCC [35-41]. Nevertheless, a recent paper has confirmed HPV as an independent risk factor for OSCC compared to other known factors such as alcohol and smoking [42]. Several HPV genotypes (1, 2, 3, 4, 6, 7, 10, $11,13,16,18,31,32,33,35,55,57)$ have been isolated from oral lesions [12, 43-45]. However, in OSCC, the most commonly HPV genotype detected is 16 , which has been demonstrated in $90-95 \%$ of all HPV positive neoplasms, followed by HPV 18 and HPV 31 [45-47].

This study was performed on a Sardinian population, which presents genetic homogeneity compared to other known populations in Europe, including the Italian population [48]. Furthermore, a highly sensitive/specific molecular methodology such as nested PCR followed by capillary sequencing was used [49]. These results confirm the prevalence of HPV-DNA in OSCC and also that HPV 16 is the most frequent genotype. The findings of the present study are in agreement with those reported by Miller et al. [50] and Anaya-Saavedra et al. [43] in two recent studies, suggesting that HPV 16 represents a risk factor in the etiopathogenesis of a subset of OSCC.

Despite the presence of low-risk, HPV (29.3\% HPV-6 and $2.4 \% \mathrm{HPV}-55)$ is according to the results of Herrero et al. [26] and other authors [44, 51, 52] who have demonstrated a malignant degeneration of papillomas induced by low-risk HPV. For example Chang et al. [44] reported that HPV 6 was also found in squamous cell carcinoma. In addition the same bibliographic data showed that an association between multiple infection (HPV 6, HPV 11 and HPV 16) is required for the development of malignant lesions [39]. Our results give us the basis to further determine how many virus' presence could be fundamental in the carcinogenesis process through the study of the HPV DNA integration.

In our study we observed a different frequency between genders; in fact a major presence of HPV-DNA results in males compared to females, as has been described in previous studies [53]. Moreover, this finding indicates that higher positivity may be the result of accumulated lifetime exposure to HPVs. The oral cavity is the anatomic site with the most frequent exposure to viruses and we observed an increase in HPV positivity with age (Fig. 4) in accordance to many papers $[47,54,55]$. This increment may be explained by the fact that different factors can be involved in the malignant process such as: immune defences [56], nutritional deficiencies [57], traumatisms inflicted by fractured teeth, incongruous restorations or prostheses [58, 59], and poor oral hygiene [60] which worsens with an increase in age. Moreover, according to our findings, HPV is a specific risk factor for the development of OSCC in association with other important risks i.e. smoking and alcohol [61-65]. 


\section{CONCLUSION}

Our data support the presence of high frequency of HPV 16 in oral cancer, but also suggest the possibility of an involvement of low-risk HPVs as a cofactor in this malignant process; in this context the age of the patients plays a central role in the cancer onset. Moreover, the results of this study, probably because of small sample size, did not show the association significantly among HPV and tobacco and alcohol use. Next step, to verify the real HPV role in carcinogenesis, will be the study of the possible HPV infection determined by the integration in the human genome confirmed by the study of E6 and E7 mRNA expression [14].

\section{ACKNOWLEDGEMENTS}

This work was funded by Italian MIUR (Ministry of the Instruction, University and Research) by PRIN 2003 Programs of Research National Interest.

\section{REFERENCES}

[1] Nevile BW, Damm DD, Allen CM, Bouqout JE. Oral \& Maxillofacial Pathology, 2nd ed. Phila-delphia: WB Saunders; 2002: 356-66.

[2] Greenberg MS, Glick M. Burket's Oral Medicine, 10th ed. Hamilton: BC Decker Inc; 2008: 153-60.

[3] Seoane J, Warnakulasuriya S, Varela-Centelles P, Esparza G, Dios PD. Oral cancer: experiences and diagnostic abilities elicited by dentists in North-Western Spain. Oral Dis 2006; 12: 482-92.

[4] Lawoyin JO, Lawoyin Do, Fasola Ao, Kolude B. Intra-oral squamous cell carcinoma in Nigerians under 40 years of age: a clinicopathological re-view of eight cases. Afr J Med Sci 2005; 34: 99-102

[5] World cancer report (2003) Lyon, France: International Agency for Research on Cancer 2003.

[6] Gillison ML, Koch WM, Capone RB, et al. Evidence for a causal association between human papillomavirus and a subset of head and neck cancers. J Natl Cancer Inst 2000; 92:709-20.

[7] Stoler MH BT. The biology of papillomaviruses. Pathol Case Rev 1997; 2: 1-13.

[8] Munger K, Howley PM. Human papillomavirus immortalization and transformation functions. Virus Res 2002; 89: 213-28.

[9] zur Hausen H. Papillomavirus infections - a major cause of human cancers. Biochim Biophys Acta 1996; 1288: F55-78.

[10] Campisi G, Panzarella V, Giuliani M, et al. Human papillomavirus: its identity and controversial role in oral oncogenesis, premalignant and malignant lesions. Int J Oncol 2007; 30: 813-23.

[11] Ha PK, Califano JA. The role of human papillomavirus in oral carcinogenesis. Crit Rev Oral Biol Med 2004; 115: 188-96.

[12] Furrer VE, Benitez MB, Furnes M, Lanfranchi HE, Modesti NM. Biopsy vs superficial scraping: detection of human papillomavirus $6,11,16$, and 18 in potentially malignant and malignant oral lesions. J Oral Pathol Med 2006; 35: 338-44.

[13] Castro TP, Bussoloti Filho I. Prevalence of human papillomavirus (HPV) in oral cavity and oropharynx. Braz J Otorhinolaryngol 2006; 72: 272-82.

[14] zur Hausen H. Papillomaviruses causing cancer: evasion from hostcell control in early events in carcinogenesis. J Natl Cancer Inst 2000; 92: 690-8.

[15] Kreimer AR, Clifford GM, Boyle P, Franceschi S. Human papillomavirus types in head and neck squamous cell carcinomas worldwide: a systematic review. Cancer Epidemiol Biomarkers Prev 2005; 2: 467-75.

[16] Sugiyama M, Bhawal UK, Dohmen T, Ono S, Miyauchi M, Ishikawa T. Detection of human papillomavirus-16 and HPV-18 DNA in normal, dysplastic, and malignant oral epithelium. Oral Surg Oral Med Oral Pathol Oral Radiol Endod 2003; 95: 594-600.

[17] Hubbard RA. Human papillomavirus testing methods. Arch Pathol Lab Med 2003; 127: 940-5.

[18] Husnjak K, Grce M, Magdić L, Pavelić K. Comparison of five different polymerase chain reaction methods for detection of human papillomavirus in cervical cell specimens. J Virol Methods 2000; 88: 125-34.

[19] Kleter B, van Doorn LJ, Schrauwen L, et al. Development and clinical evaluation of a highly sensitive PCR-reverse hybridization line probe assay for detection and identification of anogenital human papillomavirus. J Clin Microbiol 1999; 37: 2508-17.

[20] Fontaine V, Mascaux C, Weyn C, et al. Evaluation of combined general primer-mediated PCR sequencing and type-specific PCR strategies for determination of human papillomavirus genotypes in cervical cell specimens. J Clin Microbiol 2007; 45: 928-34.

[21] Montaldo C, Mastinu A, Quartuccio M, et al. Detection and genotyping of human papillomavirus DNA in samples from healthy Sardinian patients: a preliminary study. J Oral Pathol Med 2007; 36: 482-7.

[22] Sobin LH, Fleming ID. TNM Classification of Malignant Tumors, fifth edition (1997). Union Internationale Contre le Cancer and the American Joint Committee on Cancer. Cancer 1997; 80: 1803-4.

[23] Qu W, Jiang G, Cruz Y, et al. PCR detection of human papillomavirus: comparison between MY09/MY11 and GP5+/GP6+ primer systems. J Clin Microbiol 1997; 35: 1304-10.

[24] Ladunga I. Finding homologs to nucleotide sequences using network BLAST searches. Curr Protoc Bioinformatics. 2002; Chap 3: Unit 3.3. Review

[25] Tong SY, Lee YS, Park JS, Namkoong SE. Human papillomavirus genotype as a prognostic factor in carcinoma of the uterine cervix. Int J Gynecol Cancer 2007; 17: 1307-13.

[26] Herrero R, Castellsagué X, Pawlita M, et al. Human papillomavirus and oral cancer: the International Agency for Research on Cancer multicenter study. J Natl Cancer Inst 2003; 95: 1772-83.

[27] Boy S, Van Rensburg EJ, Engelbrecht S, Dreyer L, van Heerden $\mathrm{M}$, van Heerden W. HPV detection in primary intra-oral squamous cell carcinomas-commensal, aetiological agent or contamination? J Oral Pathol Med 2006; 35: 86-90.

[28] Campisi G, Panzarella V, Giuliani M, et al. Human papillomavirus: its identity and controversial role in oral oncogenesis, premalignant and malignant lesions. Int J Oncol 2007; 30: 813-23.

[29] Nielsen A, Kjaer SK, Munk C, Iftner T. Type-specific HPV infection and multiple HPV types: prevalence and risk factor profile in nearly 12,000 younger and older Danish women. Sex Transm Dis 2008; 35: 276-82.

[30] Parkin DM, Louie KS, Clifford G. Burden and trends of typespecific human papillomavirus infections and related diseases in the Asia Pacific region. Vaccine 2008 19; 26: M1-16.

[31] Hikino T. In situ hybridization with novel biotinyl-tyramide: fundamental studies and its utility of the detection of human papilloma virus in tissue sections. Rinsho Byori 2007; 55: 922-9.

[32] Morgan IM, Taylor ER. Detection and quantitation of HPV DNA replication by Southern blotting and real-time PCR. Methods Mol Med 2005; 119: 349-62.

[33] Mc Kaig RG, Baric RS, Olshan AF. Human papillomavirus and head and neck cancer: epidemiology and molecular biology. Head Neck 1998; 20: 250-65.

[34] Lawton G, Thomas S, Schonrock J, Monsour F, Frazer I. Human papillomaviruses in normal oral mucosa: a comparison of methods for sample collection. J Oral Pathol Med 1992; 21: 265-9.

[35] Syrjänen KJ, Syrjänen SM, Lamberg MA, Pyrhönen S. Human papillomavirus (HPV) involvement in squamous cell lesions of the oral cavity. Proc Finn Dent Soc 1983; 79: 1-8.

[36] Syrjänen SM, Syrjänen KJ, Lamberg MA. Detection of human papillomavirus DNA in oral mucosal lesions using in situ DNAhybridization applied on paraffin sections. Oral Surg Oral Med Oral Pathol 1986; 62: 660-7.

[37] Eversole LR, Laipis PJ. Oral squamous papillomas: detection of HPV DNA by in situ hybridization. Oral Surg Oral Med Oral Pathol 1988; 65: 545-50.

[38] Padayachee A, van Wyk CW. Human papillomavirus (HPV) DNA in focal epithelial hyperplasia by in situ hybridization. J Oral Pathol Med 1991; 20: 210-214.

[39] Bouda M, Gorgoulis VG, Kastrinakis NG, et al. "High risk" HPV types are frequently detected in potentially malignant and malignant oral lesions, but not in normal oral mucosa. Mod Pathol 2000; 13: 644-53.

[40] Giovannelli L, Campisi G, Lama A, et al. Human papillomavirus DNA in oral mucosal lesions. J Infect Dis 2002; 185: 833-6. 
[41] Trottier H, Franco EL. Human papillomavirus and cervical cancer: burden of illness and basis for prevention. Am J Manag Care 2006; 12: 462-72.

[42] Miller CS, White DK. Human papillomavirus expression in oral mucosa, premalignant conditions, and squamous cell carcinoma: a retrospective review of the literature. Oral Surg Oral Med Oral Pathol Oral Radiol Endod 1996; 82: 57-68.

[43] Anaya-Saavedra G, Ramírez-Amador V, Irigoyen-Camacho ME, et al. High association of human papillomavirus infection with oral cancer: a case-control study. Arch Med Res 2008; 39: 189-97.

[44] Chang F, Syrjänen S, Kellokoski J, Syrjänen K. Human papillomavirus (HPV) infections and their associations with oral disease. J Oral Pathol Med 1991; 20: 305-17.

[45] Schwartz SR, Yueh B, McDougall JK, Daling JR, Schwartz SM. Human papillomavirus infection and survival in oral squamous cell cancer: a population-based study. Otolaryngol Head Neck Surg 2001; 125: 1-9.

[46] Ringström E, Peters E, Hasegawa M, Posner M, Liu M, Kelsey KT. Human papillomavirus type 16 and squamous cell carcinoma of the head and neck. Clin Cancer Res 2002; 8: 3187-92.

[47] Smith EM, Ritchie JM, Summersgill KF, et al. Age, sexual behavior and human papillomavirus infection in oral cavity and oropharyngeal cancers. Int J Cancer 2004; 108: 766-72.

[48] Barbujani G, Sokal RR. Genetic population structure of Italy. Geographic patterns of gene frequencies. Hum Biol 1991; 63: 25372.

[49] Lin H, Moh JS, Ou YC, et al. A simple method for the detection and genotyping of high-risk human papillomavirus using seminested polymerase chain reaction and reverse hybridization. Gynecol Oncol 2005; 96: 84-91.

[50] Miller CS, Johnstone BM. Human papillomavirus as a risk factor for oral squamous cell carcinoma: a meta-analysis, 1982-1997. Oral Surg Oral Med Oral Pathol Oral Radiol Endod 2001; 91: 622-35.

[51] Go C, Schwartz MR, Donovan DT. Molecular transformation of recurrent respiratory papillomatosis: viral typing and p53 overexpression. Ann Otol Rhinol Laryngol 2003; 112: 298-302.

[52] Reidy PM, Dedo HH, Rabah R, et al. Integration of human papillomavirus type 11 in recurrent respiratory papillomaassociated cancer. Laryngoscope 2004; 114: 1906-09.

[53] Marais DJ, Sampson C, Jeftha A, et al. More men than women make mucosal IgA antibodies to Human papillomavirus type 16
(HPV-16) and HPV-18: a study of oral HPV and oral HPV antibodies in a normal healthy population. BMC Infect Dis 2006; 6: 95.

[54] Cruz IB, Snijders PJ, Steenbergen RD, et al. Age-dependence of human papillomavirus DNA presence in oral squamous cell carcinomas. Eur J Cancer B Oral Oncol 1996; 1: 55-62.

[55] Dunne EF UE, Sternberg M, McQuillan G, Swan DC, Patel SS, Markowitz LE. Prevalence of HPV infection among females in the United States. JAMA 2007; 28: 809-13.

[56] Lesourd B. Nutritional factors and immunological ageing. Proc Nutr Soc 2006; 65: 319-25.

[57] Bologna-Molina RE, Castaneda-Castaneira RE, Molina-Frechero N, Perez-Rodriguez E. Human papilloma virus and its association with oral cancer. Rev Med Inst Mex Seguro Soc 2006; 44: 147-53.

[58] Perez MA, Raimondi AR, Itoiz ME. An experimental model to demonstrate the carcinogenic action of oral chronic traumatic ulcer. J Oral Pathol Med 2005; 34: 17-22.

[59] Czerninski R, Kaplan I, Almoznino G, Maly A, Regev E. Oral squamous cell carcinoma around dental implants. Quintessence Int 2006; 37: 707-11.

[60] Rosenquist K. Risk factors in oral and oropharyngeal squamous cell carcinoma: a population-based case-control study in southern Sweden. Swed Dent J Suppl 2005; 179: 1-66.

[61] Boffetta P, Mashberg A, Winkelmann R. Carcinogenic effect of tobacco smoking and alcohol drinking on anatomic sites of the oral cavity and oropharynx. Int J Cancer 1992; 52: 530-3.

[62] Lee CH, Wu DC, Lee JM, et al. Carcinogenetic impact of alcohol intake on squamous cell carcinoma risk of the oesophagus in relation to tobacco smoking. Eur J Cancer 2007; 43: 1188-99.

[63] Agudelo D, Quer M, Leon X Díez S, Burgués J. Laryngeal carcinoma in patients without a history of tobacco and alcohol use. Head Neck 1997; 19: 200-4.

[64] Wiseman SM, Swede H, Stoler DL, et al. Squamous cell carcinoma of the head and neck in nonsmokers and nondrinkers: an analysis of clinicopathologic characteristics and treatment outcomes. Ann Surg Oncol 2003; 10: 551-7.

[65] Farshadpour F, Hordijk GJ, Koole R, Slootweg PJ. Non-smoking and non-drinking patients with head and neck squamous cell carcinoma: a distinct population. Oral Dis 2007; 13: 239-43.

(C) Montaldo et al.; Licensee Bentham Open.

This is an open access article licensed under the terms of the Creative Commons Attribution Non-Commercial License (http: //creativecommons.org/licenses/by-nc/ 3.0/) which permits unrestricted, non-commercial use, distribution and reproduction in any medium, provided the work is properly cited. 